\title{
Monte-Carlo tree search enhancements for one-player and two-player domains
}

Citation for published version (APA):

Baier, H. (2015). Monte-Carlo tree search enhancements for one-player and two-player domains.

[Doctoral Thesis, Maastricht University]. Maastricht University. https://doi.org/10.26481/dis.20151124hb

Document status and date:

Published: 01/01/2015

DOI:

10.26481/dis.20151124hb

Document Version:

Publisher's PDF, also known as Version of record

\section{Please check the document version of this publication:}

- A submitted manuscript is the version of the article upon submission and before peer-review. There can be important differences between the submitted version and the official published version of record.

People interested in the research are advised to contact the author for the final version of the publication, or visit the DOI to the publisher's website.

- The final author version and the galley proof are versions of the publication after peer review.

- The final published version features the final layout of the paper including the volume, issue and page numbers.

Link to publication

\footnotetext{
General rights rights.

- You may freely distribute the URL identifying the publication in the public portal. please follow below link for the End User Agreement:

www.umlib.nl/taverne-license

Take down policy

If you believe that this document breaches copyright please contact us at:

repository@maastrichtuniversity.nl

providing details and we will investigate your claim.
}

Copyright and moral rights for the publications made accessible in the public portal are retained by the authors and/or other copyright owners and it is a condition of accessing publications that users recognise and abide by the legal requirements associated with these

- Users may download and print one copy of any publication from the public portal for the purpose of private study or research.

- You may not further distribute the material or use it for any profit-making activity or commercial gain

If the publication is distributed under the terms of Article $25 \mathrm{fa}$ of the Dutch Copyright Act, indicated by the "Taverne" license above, 


\title{
STATEMENTS
}

\author{
belonging to the dissertation \\ Monte-Carlo Tree Search Enhancements \\ for One-Player and Two-Player Domains \\ by Hendrik Baier
}

1. Nested Monte-Carlo Tree Search is an effective generalization of MCTS for one-player games, especially with longer time settings (this thesis, Chapter 4).

2. Beam Monte-Carlo Tree Search is an effective generalization of MCTS for one-player games, especially with shorter time settings (this thesis, Chapter 5).

3. Embedding $\alpha \beta$ searches into MCTS can lead to better play in two-player games, even without an evaluation function (this thesis, Chapter 7).

4. Using $\alpha \beta$ searches to provide prior knowledge for MCTS can result in a stronger player than either $\alpha \beta$ or MCTS on their own (this thesis, Chapter 8).

5. People talking about AI in public are either very enthusiastic because they don't know AI, or very afraid because they don't know AI.

6. AI is the science of programming skills we have but don't understand; game $\mathrm{AI}$ is the art of having fun in the process.

7. All of science is like MCTS: You exploit existing knowledge, explore in a promising direction, go on a semi-random $\mathrm{PhD}$ trajectory, and in the end any outcome is a contribution.

8. "Great research universities must insist on independence from government and on the exercise of academic freedom." Alan Dershowitz

9. All work and no play makes Jack an uninspired game AI researcher.

10. It takes a village to raise a $\mathrm{PhD}$.

11. Don't believe everything you think. 